\title{
Perimeter-Area Ratios and Thermal Discomfort Due To Excess Heat In Rural Mud Architecture of Jharkhand: A Study Through Simulation and Temperature Measurements In Composite Climate
}

\author{
Janmejoy Gupta(1), Dr Manjari Chakraborty(2) \\ (1) Assistant Professor, Deptt. of Architecture, BIT Mesra, Ranchi, Jharkhand, India. \\ (2) Professor \& Head, Department of Architecture, BIT Mesra, Ranchi, Jharkhand, \\ India.
}

\begin{abstract}
Mud huts with clay-tiled or thatched roofs are an integral component of Jharkhand's vernacular architecture. Available literature suggests that more compact a dwelling unit, lesser is the heat gained by radiation by that dwelling unit in composite type of climate. In this study, ten different dwelling units with different perimeter-area ratios, but similar in all other respects, are recreated digitally and simulated through Autodesk Ecotect (Version 2011) software to generate their total number of discomfort hours inside them due to excess heat. Thereafter the correlation of their perimeter to area ratios to the total number of discomfort hours due to excess heat inside each of them is worked out. The computer software simulation results are verified by actual temperature measurements taken in peak summer in each of the ten dwelling units chosen for study. A moderate degree of correlation (0.48) is found to exist between perimeter-area ratios and total number of discomfort hours due to excess heat. However, dwellings with very similar perimeter-area ratios are found to have widely varying total number of discomfort hours due to excess heat. This fact is further verified by taking temperature measurements in the hottest part of the year, which show that the temperatures recorded in those dwelling units which show more number of discomfort hours due to excess heat, also show corresponding higher temperatures as compared to those dwellings which show less number of discomfort hours due to excess heat. Also, the same circular dwelling with thatched roof as actually exists on site shows lower peak summertime measured temperature than the simulated peak summertime temperature of the same dwelling unit with clay-tiled roof, all other conditions about the two huts being the same, illustrating the better insulation properties of thatch.
\end{abstract}


Key-words: Mud huts, clay-tiled roof, thatch, perimeter-area ratio, simulations, temperature-measurements, correlation, discomfort, excess heat.

\section{Jharkhand: Location and Climate}

Jharkhand is a state located in the eastern part of India. In Sanskrit, the word Jharkhand means 'the Land of forests'. Jharkhand has, as per the 2011 census, $75.9 \%$ of its total population living in rural areas, with a sizeable tribal population. It is in this context that the development of proper rural architecture is important. With the energy crisis deepening, the role of the built environment becomes more significant.

Ranchi district is the study area of this paper and lies in the centre of Jharkhand. The Tropic of Cancer passes through Ranchi and its geographical location is 23.38 degrees north latitude and 85.33 degrees east longitude. Ranchi is at a moderately high altitude, with an altitude of 655 meters.

As per the National Building Code's climate classification, most of Jharkhand falls in the composite climatic region, with hot, dry summers and cold winters. (Refer Figure 1) It has a hot and dry summer, with maximum temperatures up to 42 degree centigrade, followed by a humid season with monsoon rains. With the departure of the monsoon it gradually becomes comfortable in autumn, followed by a relatively short winter (3 months) with the cloudy and wet as well as sunny periods. In winter minimum temperatures drops till 3 degree centigrade. Before the summer returns there is a comfortable but short spring season.

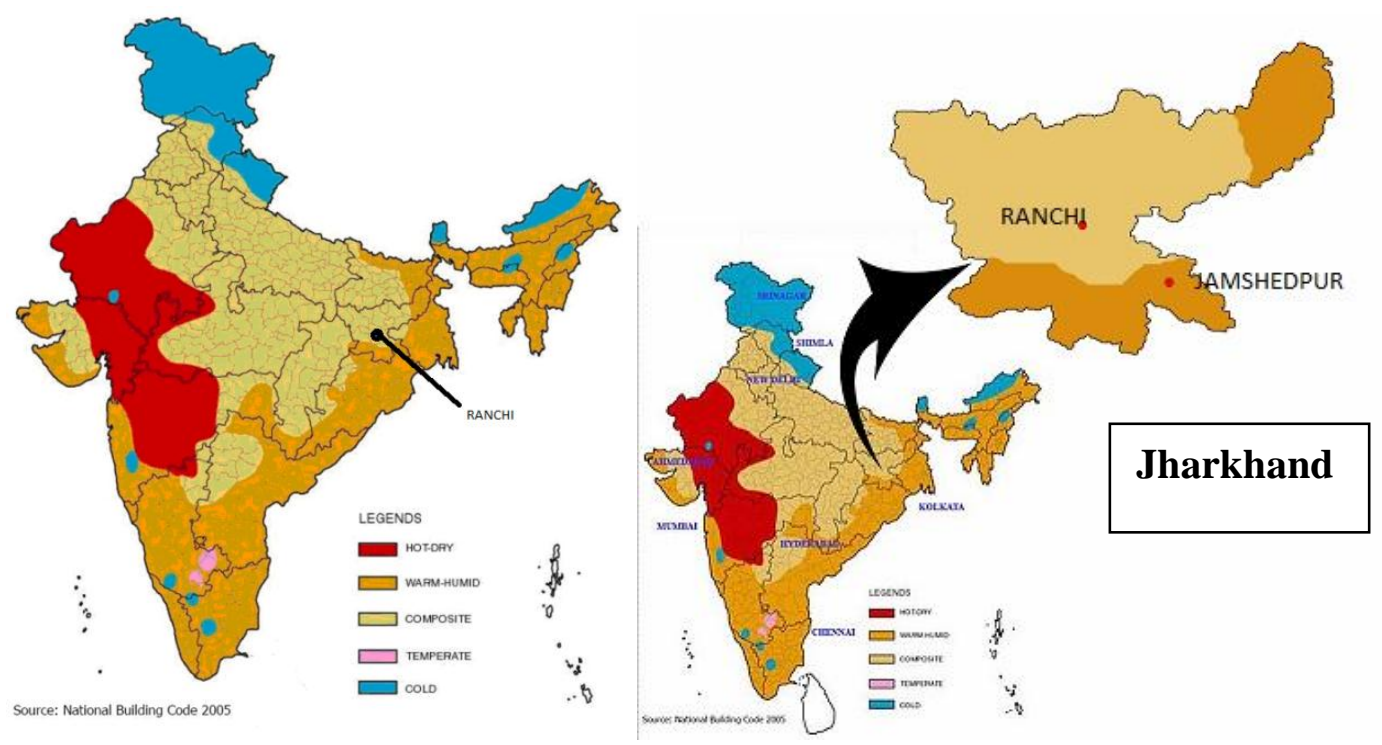

Figure 1: NBC climatic classification putting Ranchi district in Composite Climate Zone.

\section{Study Villages in Ranchi District}

The huts chosen for the study are located in the twin villages of Masu and Jamuari village, which is located on the banks of the Subarnarekha river, about $20 \mathrm{kms}$ from Central Business District (CBD) of Ranchi. (Figure 2) Masu consists of fifty mud 
dwelling units and Jamuari consists of thirty mud dwelling units. (Figures 3 \& 4) Out of these total eighty odd mud dwelling units, ten types of mud dwelling units were identified, which have been analyzed in this paper.

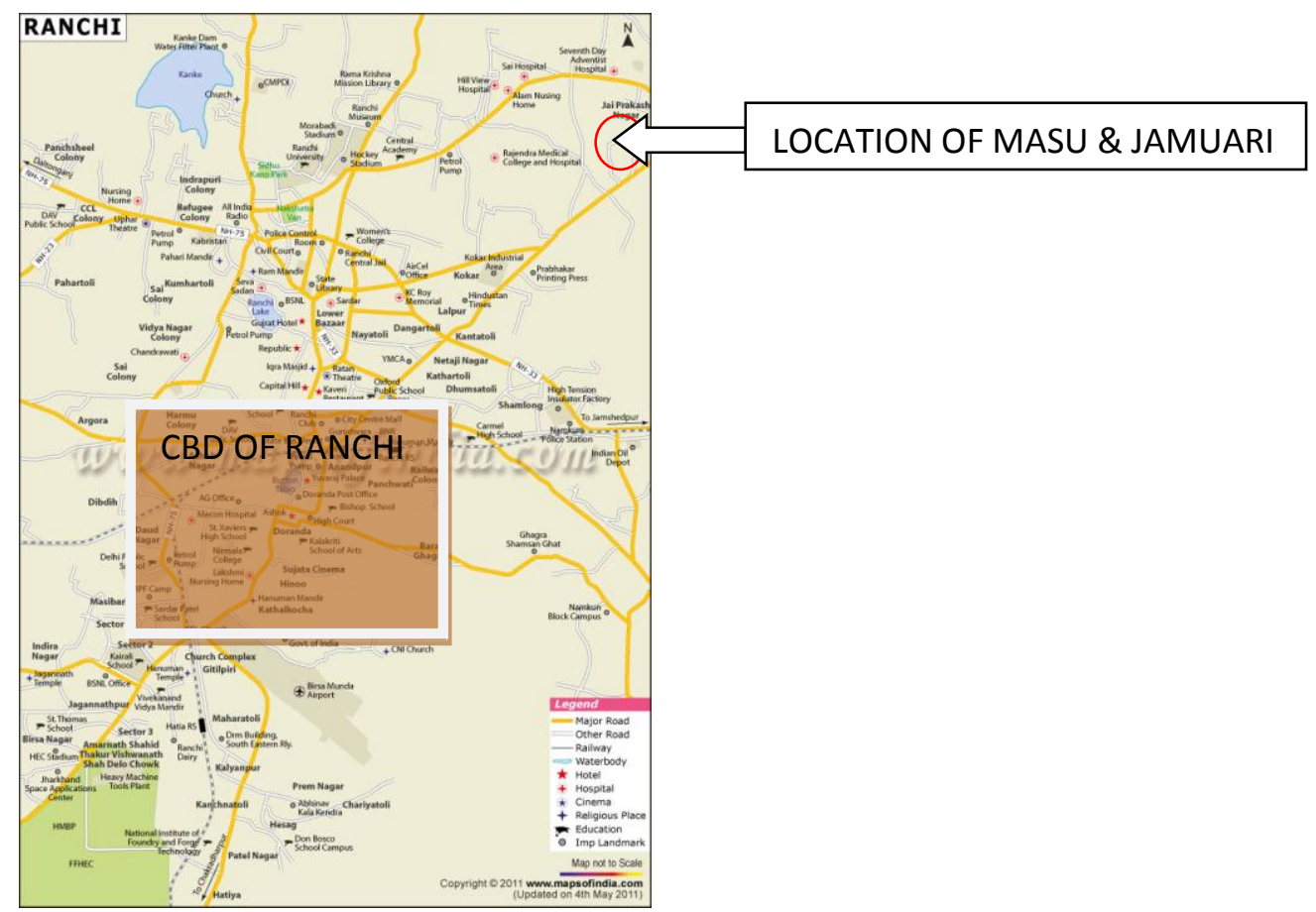

Figure 2: Study villages' location with respect to Ranchi City CBD

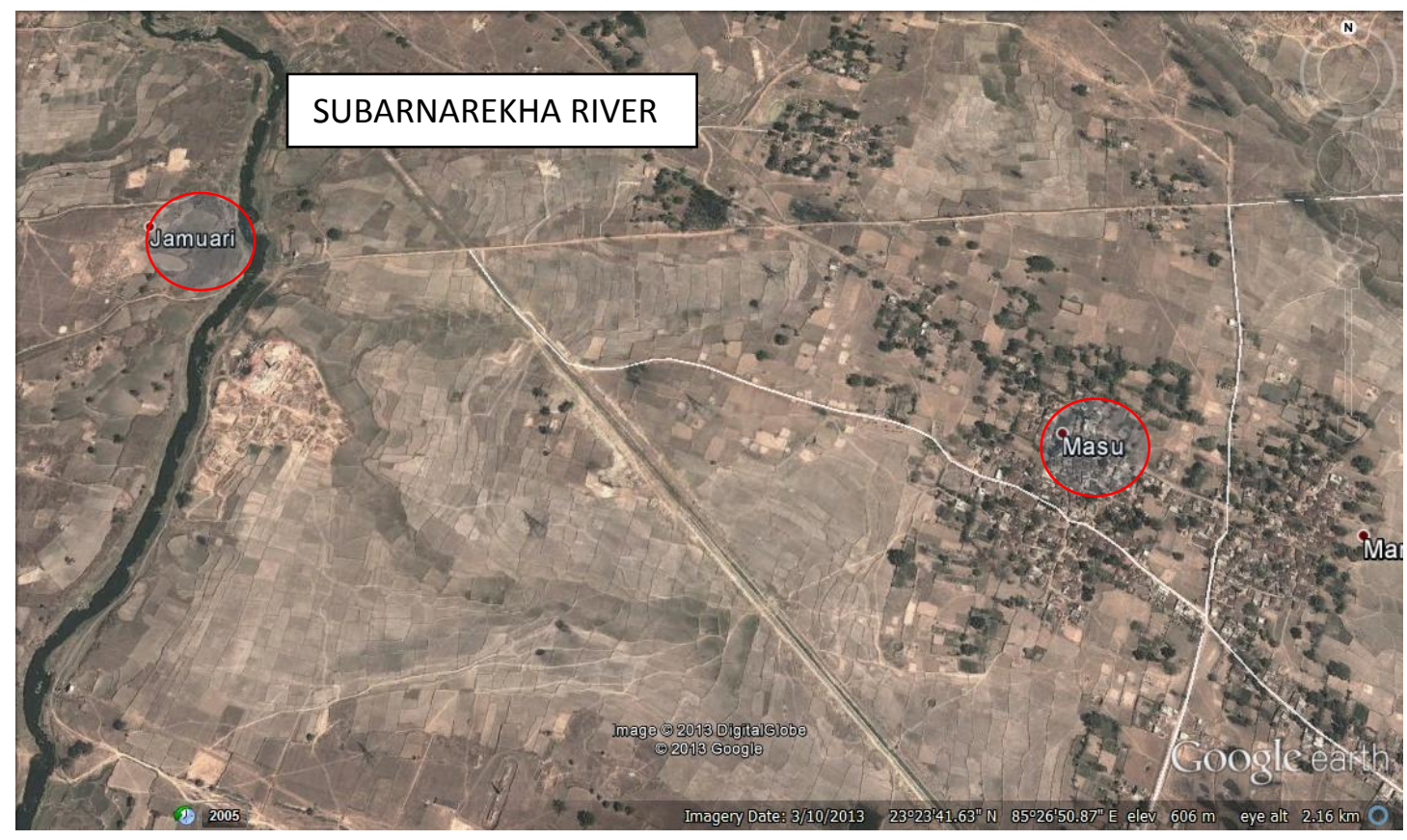

Figure 3: Twin Villages of Jamuari \& Masu near the River Subarnarekha 


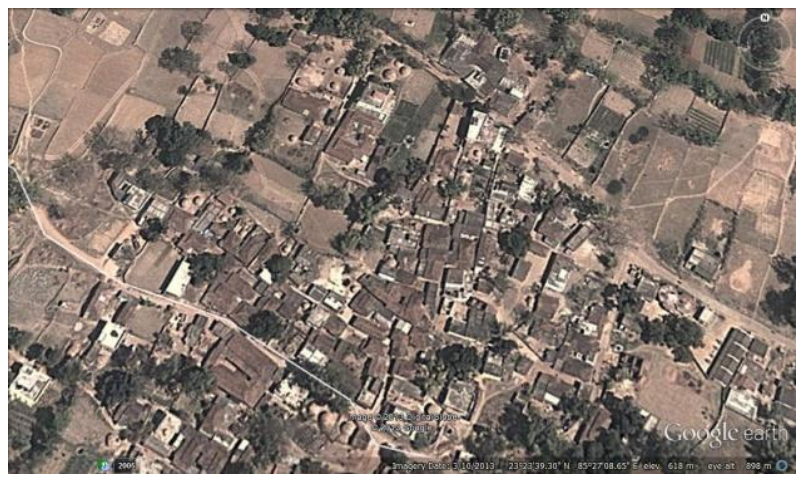

Figure 4: Arrangement of dwelling units in Masu Village

\section{Jharkhand Vernacular Mud Huts}

The walls of the rural dwelling units in Jharkhand are made up of mud mixed with cow dung, chopped straw, and gravel-pieces or stones, which improves their tensile strength. The pitched roofs are made up of burnt clay tiles or thatch. (Refer Figure 5)

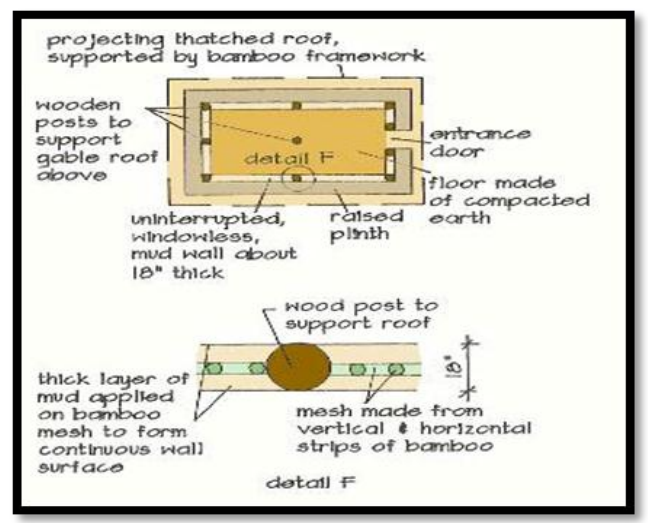

Figure 5: Typical Vernacular hut of Jharkhand (Reproduced from Dhar, 1992)

These mud-houses are low energy-intensive in construction and have very less embodied energy as compared to conventional brick and concrete buildings. (Refer Table 1)

Table 1: A Comparative Assessment of Embodied Energy of Mud Huts Vis A Vis Traditional Brick Concrete LIG House

\begin{tabular}{|l|l|}
\hline $\begin{array}{l}\text { Description of Items/Materials Used In The } \\
\text { House }\end{array}$ & $\begin{array}{l}\text { Embodied Energy (Mega } \\
\text { Joules) }\end{array}$ \\
\hline $\begin{array}{l}\text { Traditional House Using Conventional Materials } \\
\text { Such As Brick Masonary In Foundation \& In Walls } \\
\text { \& Rcc In Roof. Wall Thickness Equals 23 Cms. }\end{array}$ \\
\hline Mud, Straw, Cow Dung, Gravel, Clay Tiles. & 20,000 \\
\hline
\end{tabular}


***The quantity of materials required for the installation of electrical, mechanical, plumbing, sewage \& drainage systems is not included.

\section{CSIR- Central Building Research Institute (CBRI)}

Mud houses have a lot of potential to provide both reasonable living conditions and thermal comfort at affordable prices for the rural people if properly dealt with. $30 \%$ of the world's total population lived in earthen structures in 1990 as reported by Cofirman et al, (1990). [1]

Internationally, Binici et al (2005) [2] and (2007) [3], in their study of fibre reinforced mud bricks surmised that the fibre reinforced mud bricks met the expected technical performance for the thermal isolation and mechanical properties, according to ASTM (ASTM: American Society for Testing \& Materials) and Turkish standards. The mechanical properties of waste materials and some stabilisers were investigated thoroughly and some conclusions drawn. The fibre reinforced mud brick house had been found to be superior to the concrete brick house for keeping indoor temperatures stationary during the summer and winter.

That mud huts offer a reasonable level of thermal comfort inside them is a wellresearched and known fact. Mud huts keep inside temperatures lower than outside temperatures in summer daytime and inside temperatures higher than outside temperatures in winter nighttime. In this research exercise the extent of linear correlation between the perimeter-area ratio and the amount of thermal discomfort inside the huts due to excess heat, keeping the heights and other parameters for all studied huts same, is found out in composite climatic region. Simultaneously, also the thermal performance of the studied types of dwelling units are studied and areas of good and poor thermal performance identified through simulation based methods.

\section{Research Hypothesis: Perimeter-Area Ratio and Heat Gain In Dwelling Units}

Krishan et al(2001) states that in case of radiative gains or losses, the perimeter is a crucial factor. Greater the Perimeter to Area ratio (P/A), greater the radiative heat gain during the day and greater the heat loss at night. Similarly, smaller the P/A ratio, the lesser will the heat gain be during the day and the lesser the loss at night. In hot climates the P/A ratio should be kept to a minimum to cause minimum heat gain. [4]

Now, smaller the P/A ratio, the lesser will the heat gain be during the day.

This implies that smaller the P/A ratio, lesser will be the number of thermal discomfort hours due to excess heat.

The hypothesis, thus, is that, in composite climatic regions, Perimeter to Area Ratio shows high degree of positive correlation to amount of thermal discomfort hours due to excess heat, i.e. higher the perimeter to area ratio more is the thermal discomfort inside the dwelling unit due to excess heat.

In other words, in composite climate, with the heights of the dwellings remaining same, lower the perimeter to area ratio, i.e. more compact the dwelling unit, more is the thermal comfort inside the dwelling unit in the hotter months. 
Bansal and Minke (1988) [5] in their exhaustive study of rural dwelling units in the different climatic regions of India also stated that in the composite climatic area, compact floor plans show better thermal performance. Szokolay (2004) [6] also states that the three dimensional extrapolation of perimeter-area ratio, i.e. the surface areato-volume ratio should be kept to a minimum in severe climates, i.e. it is advisable to present the least surface-area for a given volume. He further states that in severe climates a compact plan is always better than a broken-up and spread out arrangement. As per Koenigsberger et al (1997) in composite climates moderately compact internal planning of houses will be of benefit for most of the year. Courtyard type buildings are very suitable. Compact internal planning implies low perimeter by area ratio.

\section{Materials \& Methods: Simulation Methodology}

For simulating climate conditions of Ranchi and studying extent of thermal discomfort due to excess heat in each of the ten subtypes of mud huts, the Autodesk software Ecotect (2011 Version) has been used. ISHRAE (under ASHRAE) provide general climatic data for building design and manual load calculations for different areas of India and cities, as has been used for Ranchi District in the form of computerized EPW Climate Data in this case. The ten types of studied mud huts have been reconstructed in Ecotect and material properties assigned to the roof and walls as per material of construction used in the actual huts. The material properties assigned are $\mathrm{U}$ values (thermal transmissivity values).

One of the key factors on which thermal performance of a building depends is the thermal transmissivity (or U value) of the building materials used in constructing the building wall, roof, etc. In this case all building walls are made of $500 \mathrm{~mm}$ rammed earth and roof is made of bamboo-thatch in one case and bamboo-Mangalore Tiles in the remaining cases.

Thermal Transmittance, also known as U-value, is defined as the amount of heat in watts passing through $1 \mathrm{sq}$ meter of a medium or a combination of media when a temperature difference of 1 Kelvin exists between the two sides. It is expressed in watts per square metre per kelvin, or $\mathrm{W} / \mathrm{m}^{2} / \mathrm{K}$.

Symbolically, $\mathrm{U}=\mathrm{k} / \mathrm{l}$, where 1 is thickness of material and $\mathrm{k}$ is the thermal conductivity in Watt/meter/Kelvin.

The lesser the $U$ value of the building material, more is the resistance offered by the building material to the flow of heat from outside to inside or from inside the building to outside. In other words, lesser is the $U$ value, more is the insulative property of the building material. $U$ value differs from case to case, ranging from the $\mathrm{U}$ value of mud-bamboo wall section $500 \mathrm{~mm}$ thick being $3.44 \mathrm{~W} / \mathrm{sq} \mathrm{m} \mathrm{K}$ and the $\mathrm{U}$ value for Mangalore Tiles- bamboo framework of standard thickness being $3.1 \mathrm{~W} / \mathrm{sq}$ $\mathrm{m} \mathrm{K}$. The $\mathrm{U}$ value of thatch-bamboo framework of standard thickness is $0.35 \mathrm{~W} / \mathrm{sq} \mathrm{m}$ $\mathrm{K}$.

All the studied dwelling units are placed on site with their longer sides oriented along the East-West axis, which is considered to be best orientation for least heat gain in summer and most heat gain in winter as per Ecotect Software simulation as shown 
in Figure 6. Also all the dwelling units have clay-tiled roofs for uniformity in calculating number of hours of thermal discomfort due to excess heat except one thatched roof circular mud hut. However, when simulation to generate total number of discomfort hours due to excess heat is carried out, for finding out the extent of correlation between perimeter area ratio and number of discomfort hours due to excess heat, then the circular mud hut is also considered to have clay-tiled roof for uniformity in simulation. The software generated thermal discomfort results have been validated by real time temperature measurements taken inside the studied mud houses using digital thermometer and data loggers. (Refer Figure 7 \& Figure 8).

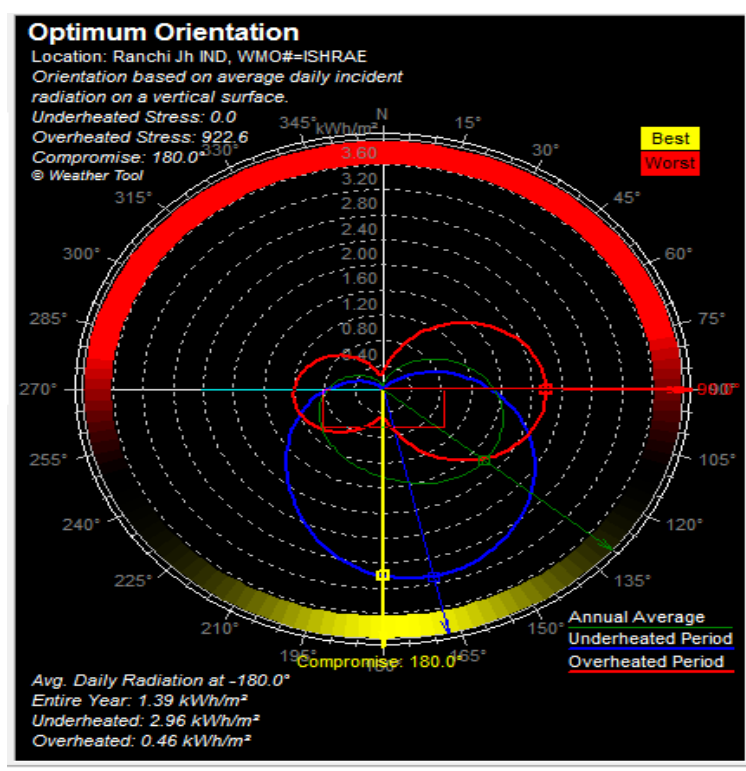

Figure 6: Optimum East-West orientation of longer sides for least heat gain in summer \& maximum heat gain in winter in composite type of climate prevalent in Ranchi as per Autodesk Ecotect Simulation. (Built form represented by red rectangle)

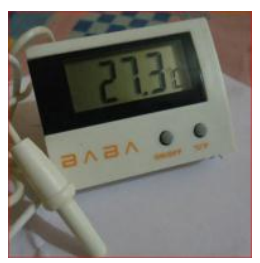

Figure 7: Digital Thermometer used for measuring temperature inside and outside mud hut.

For measuring the hourly temperatures inside the huts, data loggers are used. Three-channel data loggers collected data on temperature to study variations over a day. These data loggers were installed at the centre of the room at a height of $1-1.5 \mathrm{~m}$. The height of $1-1.5 \mathrm{~m}$ is based on the average human height while sitting or standing (Das, 2006). [7] All data were automatically sampled at an interval of one hour (60 
minutes). (Figure 8). For measuring outside temperatures, digital thermometer is used.

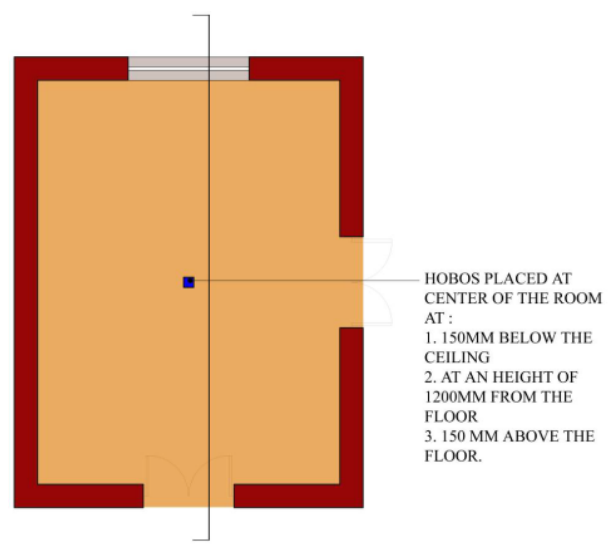

Figure 8: Diagram showing typical locations of the data logger installed at the centre of the room to gather climatic data in a room.

All the dwelling units have openings on both the North as well as South walls to allow for adequate cross-ventilation.

(ASHRAE: American Society of Heating, Refrigerating and Air Conditioning Engineers)

(ISHRAE: Indian Society of Heating, Refrigerating and Air Conditioning Engineers)

\section{Comfort Model Adopted}

The Adaptive Comfort Model adopted in this case is defined in ASHRAE Standard 55. It applies to naturally ventilated spaces where people can open and close windows/voids. Their thermal response will depend partially on outdoor conditions and they will have a wider comfort range than in buildings with centralized HVAC systems. It assumes that people will adapt their clothing to the climate and that they are engaged in sedentary activities like sitting, cooking or reading.

Thermal comfort is defined by ASHRAE Standard 55-2004 as "the condition of mind that expresses satisfaction with the thermal environment." The thermal environment is those characteristics of the environment which affect a person's heat loss or gain. Ventilation rates are considered in determining comfort conditions.

All parameters of the 10 selected dwellings are similar, including the materials of construction for walls and roofs, (mud walls and clay-tiled roof) the dwelling unit heights and all the dwellings have voids on opposite walls, thereby allowing for adequate cross-ventilation. The heights of all dwelling units studied are 3.7 meters from floor to roof ridge. (2.4 meters from floor to base of roof and 1.2-1.3 meters from roof base to roof ridge.) (Total height from floor to roof ridge is approximately 3.7 meters for all studied dwelling units.)(Figure 9) 


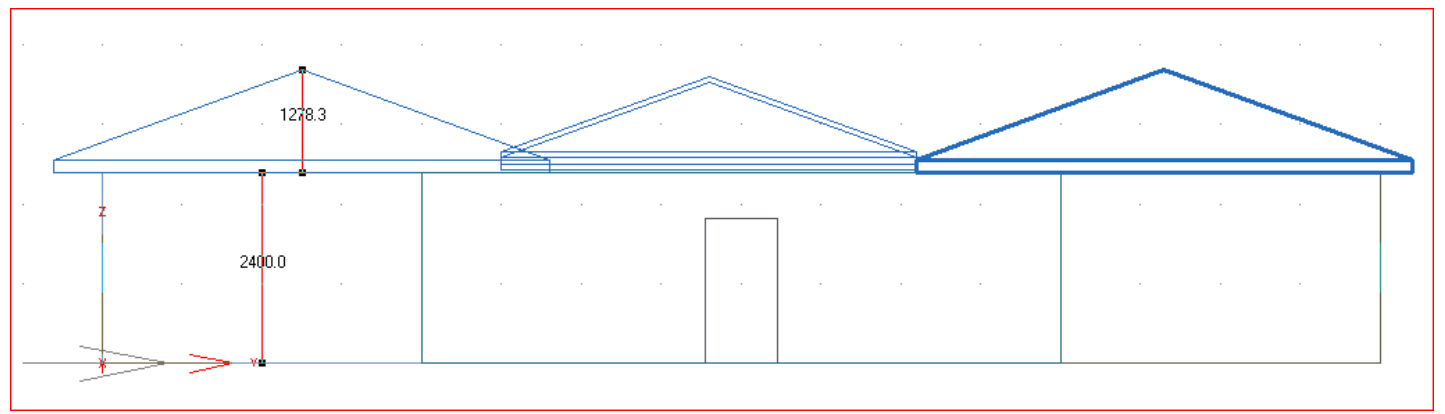

Figure 9: Standard Height of All The Studied Dwelling Units

\section{Observations}

Table 2: Table showing different types of mud dwellings studied and the number of discomfort hours inside them in a year

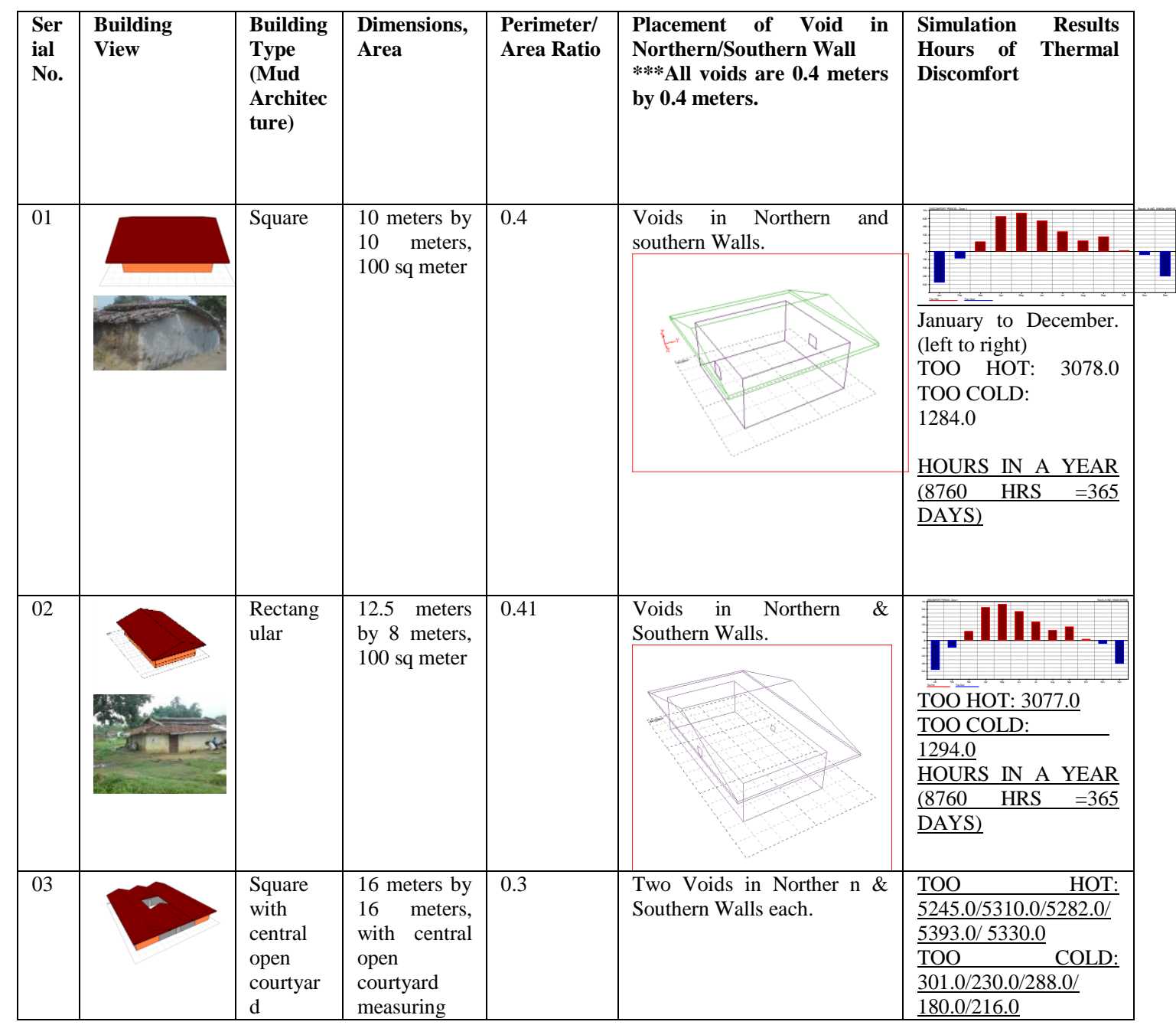




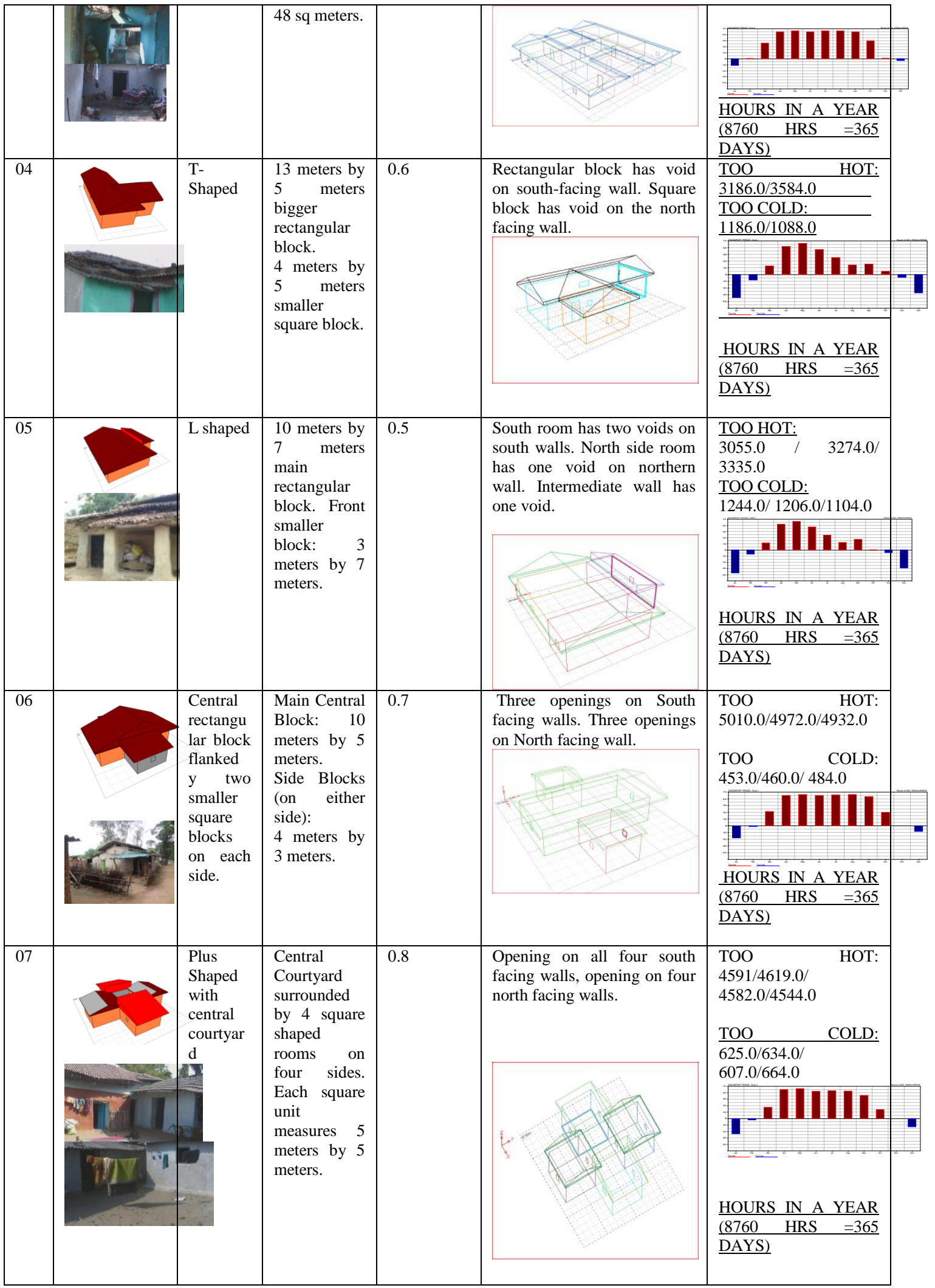




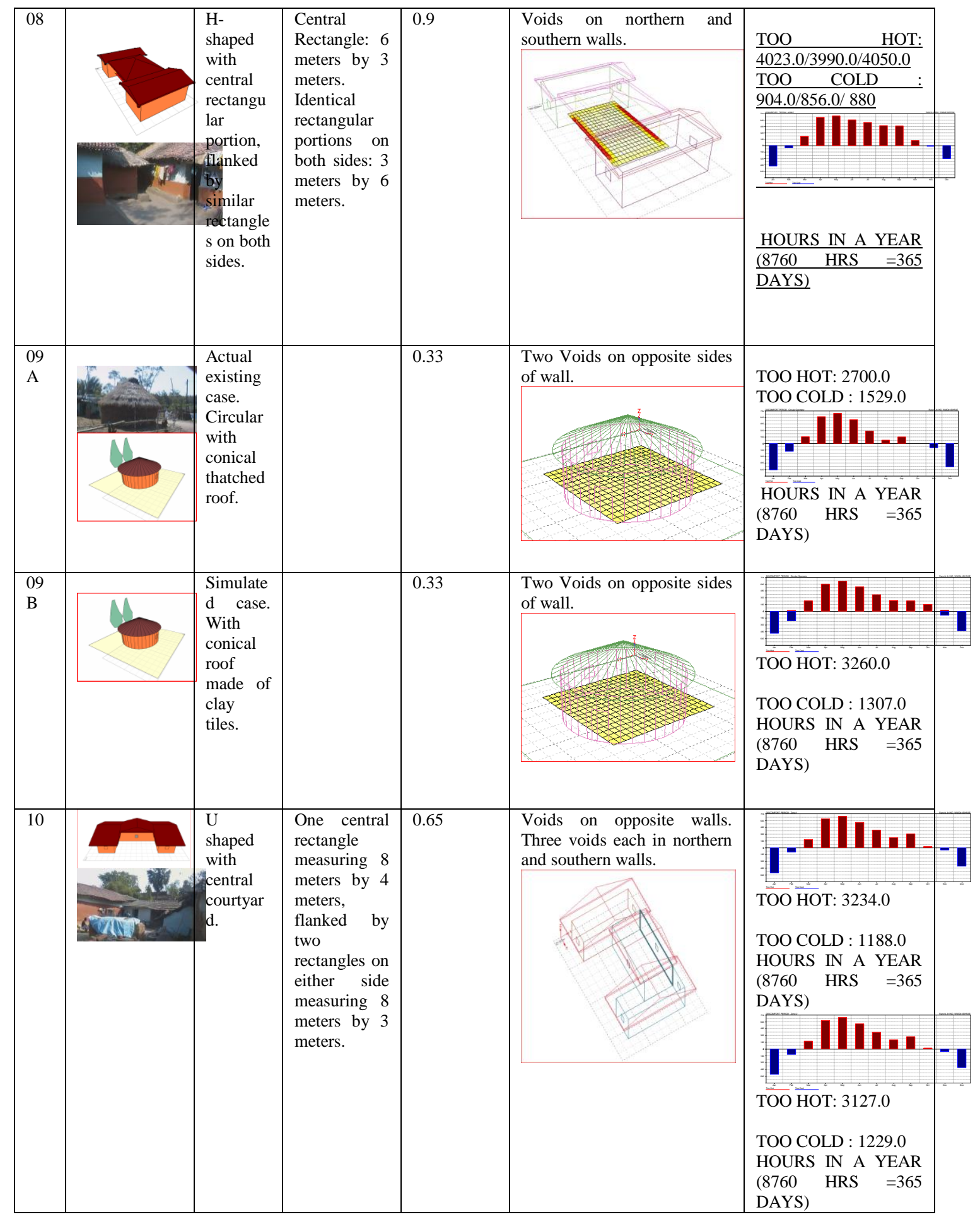




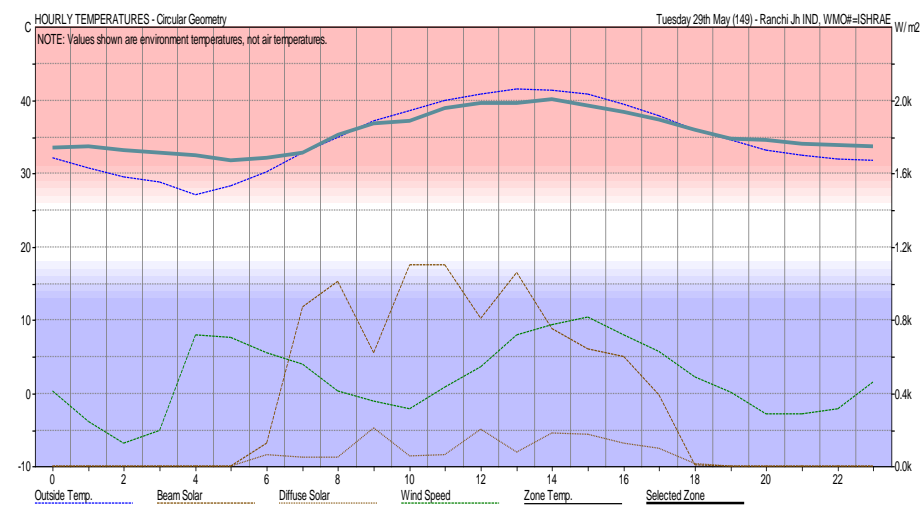

Figure 10: Simulated temperatures for simulated circular mud hut with clay-tiled roof.

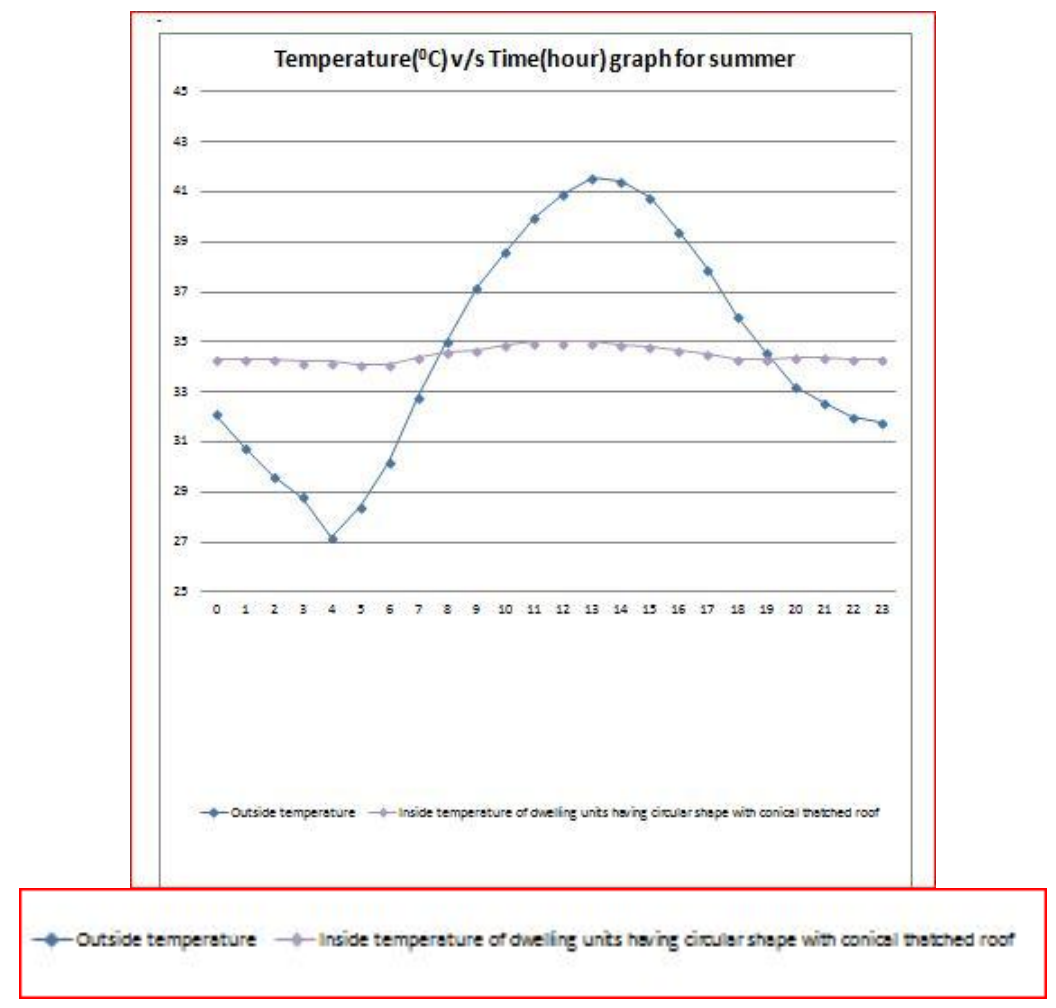

Table 3: Temperature records for mud hut with thatched roof as actually exists on site. Temperatures recorded inside mud hut and outside temperature variation through the day. 


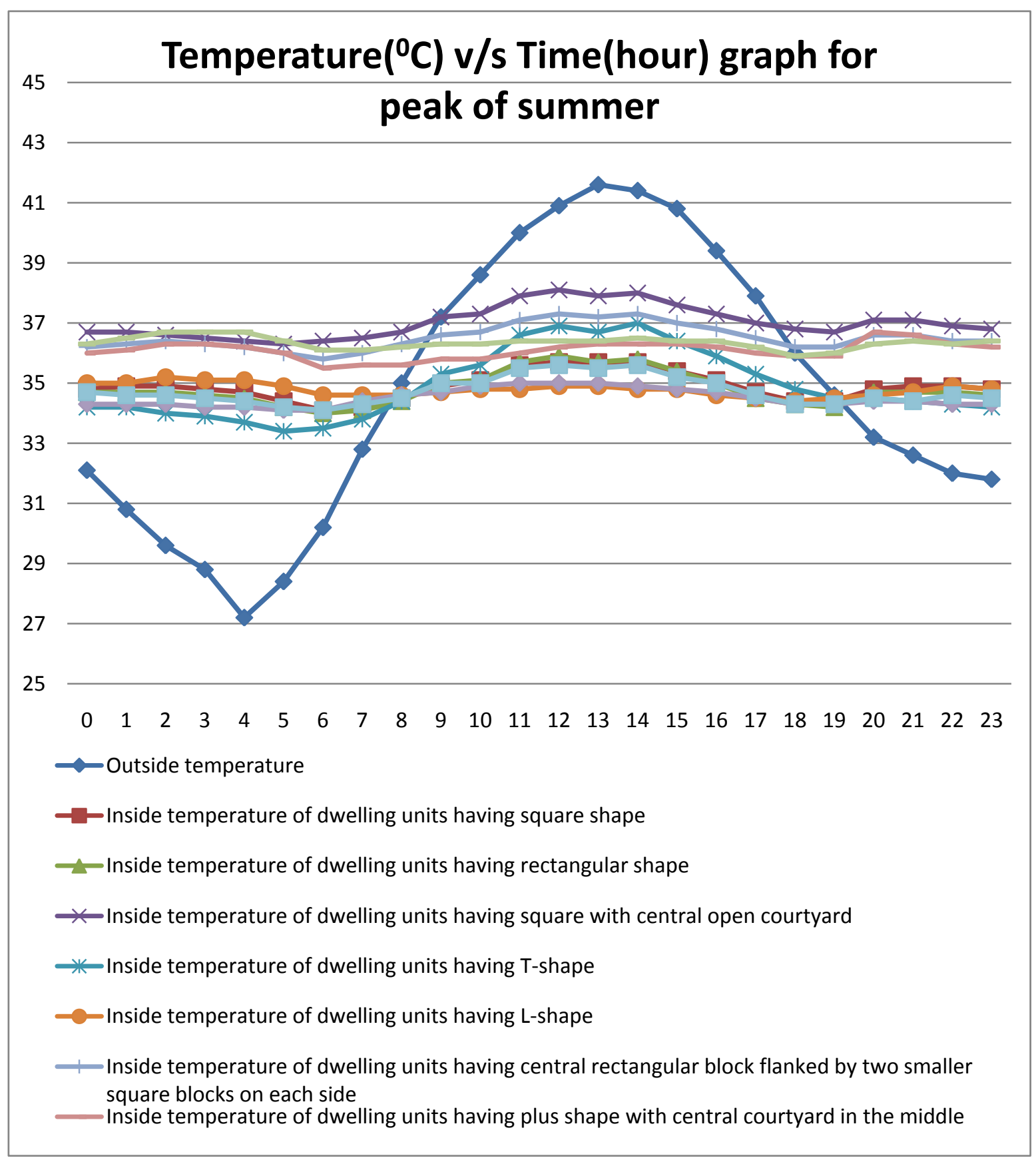

Table 4: Measured average temperature for each of the dwelling units during the hottest period of the year as per past years climate records. $\left(29^{\text {th }}\right.$ May to $4^{\text {th }}$ June $)$

Validation by Actual temperature measurements reinforces the simulation findings for the thermal discomfort levels in the different dwelling units.

All the dwelling units with higher number of discomfort hours due to extreme heat show corresponding higher measured temperatures at all times of the day in one of the hottest periods of the year ( $29^{\text {th }}$ May to $4^{\text {th }}$ June) than those amongst the studied 
dwelling units with lesser number of discomfort hours due to extreme heat as shown in table 4, thereby validating the simulation results.

For example, for the rectangular shaped dwelling unit, the dwelling unit with the least number of thermal discomfort hours due to heat, the corresponding temperatures inside the dwelling unit are on the lower side while for the square dwelling unit with central courtyard, which has the most number of thermal discomfort hours due to heat, the temperatures inside the dwelling unit are maximum, at about 3 degrees higher than the rectangular unit and other units like the circular unit, in the hottest few days of the year. (Hottest days of the year as per past years temperature records)

Also, the measured temperatures inside the thatched circular mud hut, at 2 PM in the afternoon on $29^{\text {th }}$ May is considerably lower than the circular mud hut having clay tiled roof at the same time on the same date as per the simulated temperature graph. (34 degree Celsius for the thatched mud circular hut as per measurement versus nearly 40 degree as per simulation results for the circular mud hut with clay tiled roof). (Table 3 \& Figure 10). The same thing reflects in the number of discomfort hours measurement where the circular mud hut with thatched roof has lesser number of discomfort hours due to excess heat than the circular mud hut with clay tiled roof.

\section{Calculation}

Finding out Correlation Coefficient between Surface Volume Ratio and Number of Discomfort hours in summer:

\begin{tabular}{|c|c|c|c|c|c|c|c|}
\hline Shape & $\begin{array}{l}\text { X } \\
\text { (perim } \\
\text { eter/ } \\
\text { area } \\
\text { ratio) }\end{array}$ & $\begin{array}{l}\text { Y (Number of } \\
\text { discomfort hours in } \\
\text { summer/winter) } \\
\text { (too hot hours) (as } \\
\text { per } \quad \text { Ecotect } \\
\text { Simulation Results.) }\end{array}$ & $\begin{array}{l}\mathrm{Y} \\
\text { (mean) }\end{array}$ & $\mathrm{X}($ mean $)$ & dx.dy & $\mathrm{Dx} 2$ & Dy2 \\
\hline Square & 0.4 & 3078.0 & \multirow[t]{6}{*}{3791} & \multirow[t]{6}{*}{0.56} & $\begin{array}{l}0.16^{*} 713= \\
114.08\end{array}$ & .0256 & 508369 \\
\hline Rectangular & 0.41 & 3077.0 & & & $\begin{array}{l}0.15 * 714=10 \\
7.1\end{array}$ & .0225 & 509796 \\
\hline $\begin{array}{lr}\begin{array}{l}\text { Square } \\
\text { central } \\
\text { courtyard }\end{array} & \begin{array}{r}\text { with } \\
\text { open }\end{array} \\
\end{array}$ & 0.3 & 5282.0 & & & $\begin{array}{l}0.26^{*}- \\
1491=- \\
387.66\end{array}$ & .0676 & 2223081 \\
\hline T-Shaped & 0.6 & 3186.0 & & & $\begin{array}{l}-0.04 * 605=- \\
24.2\end{array}$ & .0016 & 366025 \\
\hline L shaped & 0.5 & 3274.0 & & & $\begin{array}{l}0.06 * 517=31 \\
.02\end{array}$ & .0036 & 267289 \\
\hline $\begin{array}{l}\text { Central } \\
\text { rectangular block } \\
\text { flanked y two } \\
\text { smaller } \text { square } \\
\text { blocks on each } \\
\text { side }\end{array}$ & 0.7 & 4972.0 & & & $\begin{array}{l}-0.14 *_{-} \\
1181=165.34\end{array}$ & .0196 & 1394761 \\
\hline $\begin{array}{l}\text { Plus Shaped with } \\
\text { central courtyard }\end{array}$ & 0.8 & 4582.0 & & & $\begin{array}{l}-0.24 *_{-} \\
791=189.84\end{array}$ & .0576 & 625681 \\
\hline $\begin{array}{l}\text { H-shaped with } \\
\text { central } \\
\text { rectangular } \\
\text { portion, flanked } \\
\text { by similar } \\
\text { rectangles } \\
\text { both sides. }\end{array}$ & 0.9 & 4023.0 & & & $\begin{array}{l}-0.34 *_{-} \\
232=78.88\end{array}$ & .1156 & 53824 \\
\hline
\end{tabular}




\begin{tabular}{|l|l|l|l|l|l|l|l|}
\hline U-shaped & 0.65 & 3180 & & & $\begin{array}{l}-0.09 * 611=- \\
55\end{array}$ & .0081 & 373321 \\
\hline $\begin{array}{l}\text { Circular with } \\
\text { conical roof }\end{array}$ & 0.33 & 3260 & & & $\begin{array}{l}0.23 * 531= \\
122.13\end{array}$ & .0529 & 281961 \\
\hline \multicolumn{2}{|l|}{} & & & 729.19 & 0.3491 & 6604108 \\
\hline
\end{tabular}

$(\mathbf{r})=$ Correlation Coefficient $=729.19 /$ Square root of $(0.3491 * 6604108)=$ 729.19/1518.39=0.48

\section{Analysis}

1. A small perimeter to area ratio does not necessarily mean the dwelling unit shows good thermal performance in summer and that temperatures inside the dwelling unit are comfortable, as Case 3, i.e. courtyard sub-type dwelling unit testifies to. That dwelling unit, inspite of being compact and having a low perimeter-area ratio (0.3) shows uncomfortably high temperatures inside during the summer months and has a high number of discomfort (too hot) hours.

2. Similarly, the circular dwelling unit with clay-tiled roof and square dwelling unit with central open courtyard both have almost the same perimeter-area ratio, i.e. 0.33 and 0.3 respectively, but their total number of discomfort hours due to excess heat are very different, being 3260 hours for the circular unit and 5282 hours yearly for the square dwelling unit with central open courtyard.

3. The overall correlation coefficient between the perimeter to area ratio and the number of discomfort hours due to excess heat comes to be 0.48 . It can be at best classified as moderate degree of correlation.

4. This implies that to a moderate degree, more in the perimeter to area ratio, more is the number of discomfort hours due to excess heat. That means, lesser is the perimeter area ratio, lesser is the number of discomfort hours due to excess heat. Other factors like the amount and type of openings, amount of ventilation allowed, etc contribute to the thermal comfort. However the above mentioned factors are similar for all the studied dwelling units. Certain basic parameters like orientation of the dwelling unit, height of the dwelling unit and construction materials have been kept constant for all the ten sub-types of dwelling units.

5. For the same perimeter to area ratio and all other parameters, for the mud dwelling unit with thatched roof and with clay tiled roof, the unit with the thatched roof shows less number of hours of thermal discomfort due to excess heat as compared to the mud dwelling unit with clay tiled roof. This clearly shows the importance of materials used in thermal performance and the role of thatch as a better insulator than clay-tiled roofs.

\section{Results}

Compact dwelling units do not necessarily perform better from a thermal comfort point of view. What is however important from the point of view of comfort in the 
hotter months is that buildings should be grouped in such a way as to take advantage of prevailing breezes during the short period when air movement is necessary. This is exemplified by the $U$ shaped dwelling unit with a courtyard, which in spite of not being too compact, having a perimeter area ratio of 0.65 performs well from a thermal comfort point of view both as per simulation results and as per measured temperatures in the hotter period of the year. In stark contrast, the very compact dwelling unit, the square dwelling unit with central courtyard having a perimeter to area Ratio of 0.3 performs worse in terms of total number of discomfort hours due to excess heat as well as having considerably higher measured temperatures inside the dwellings in peak summer as compared to the $U$ shaped dwelling. Thus, low perimeter to area ratios or their three dimensional extrapolation, surface to volume ratios, manifested in the form of compact dwellings are not that important in making the inside of the dwelling unit comfortable in the hotter part of the year.

\section{References}

[1] Cofirman R, Agnew N, Auiston G, Doehne E. Adobe mineralogy: characterization of adobes from around the world. In: Proceedings of sixth International conference on the conservation of earthen architecture, Las Cruces, New Mexico; 14-19 October, 1990.

[2] Hanifi Binici, Orhan Aksogan, Tahir Shah. (2005), Investigation of fibre reinforced mud brick as a building material. Elseviers Science Direct, Construction And Building Materials, Volume 19, Pages 313-318.

[3] Hanifi Binici, Orhan Aksogan, Mehmet Nuri Bodur, Erhan Akca, Selim Kapur. (2007).Thermal isolation and mechanical properties of fibre reinforced mud bricks as wall materials. Elseviers Science Direct, Construction And Building Materials, Volume 21, Pages 901-906.

[4] Nicol, J. F., 2001. Climate and thermal comfort in India, in: Krishan, A., Baker, N., Yannas, S. and Szokolay, S.V. (Eds.), Climate responsive architecture: A design handbook for energy efficient buildings. Tata McGraw-Hill Publishing Company Limited, New Delhi, pp.

[5] Bansal,N.K. and Minke,G.,1988. Climatic zones and rural housing in India. Zentralbibliothek Publishers, pp. 62-68, 132-149.

[6] Szokolay, S.V., 2004. Heat: The Thermal Environment in Introduction to Architectural Science: The Basis of Sustainable Design. Elsevier, pp.68

[7] Das,N., 2006. Courtyards houses of Kolkata: Bioclimatic, typological and socio-cultural study. Unpublished Masters of Architecture, Kansas State University, Manhattan. 